\title{
Life history responses of Amphiascus tenuiremis (Copepoda, Harpacticoida) to mimicked predation*
}

\author{
Roberta E. Woods, Bruce C. Coull ${ }^{* *}$ \\ Belle W. Baruch Institute for Marine Biology \& Coastal Research, Marine Science Program and Department of Biological \\ Sciences, University of South Carolina, Columbia, South Carolina 29208, USA
}

\begin{abstract}
Potential demographic effects of life stage or gender specific predation on population size and composition were investigated using populations of a laboratory-reared benthic harpacticoid copepod, Amphiascus tenuiremis cf. Mielke, 1974. Control populations initially contained 100 copepodites, 100 adult males and 100 adult females. In the experimental treatments, one of these components was reduced by 90 or $50 \%$ to mimic 30 or $17 \%$ once-in-time predation impact. Number of nauplii, copepodites, adult males, adult females and total population size was recorded for each population after $21 \mathrm{~d}$ (1 generation). Abundance increased in all populations, and at both levels removal of females (female treatment) resulted in significant decreases in final total abundance. Copepodite and male removal had no significant effect on total population size. Final population composition was also affected by treatment. In the $90 \%$ removals final abundances of nauplii were significantly lower in female removal treatments. At the $50 \%$ removal level, final number of nauplii and copepodites was lower in female treatments only. Number of males was significantly lower in male treatments at both levels of removal, as was number of females in female treatments. Female specific predation had the greatest effect on these copepod populations. Total population size decreased because number of nauplii (which comprised 75 to $80 \%$ of each population) was significantly decreased. High reproductive potential, as indicated in up to 28 -fold increases in population size over 1 generation, intimated that the observed changes in population size and composition would not be enduring. Predation, imitated herein by removal, would play a small role in determining population structure of $A$. tenuiremis.
\end{abstract}

\section{INTRODUCTION}

In their discussion of the ecological role of meiofaunal harpacticoid copepods, Hicks \& Coull (1983) asked how predation by higher trophic levels influenced the structuring of benthic copepod populations. In recent years, research in meiofaunal ecology has expanded to include field and laboratory studies addressing this question (reviewed by Coull \& Palmer 1984). The full spectrum of results, from no significant impacts to declining abundance and threatened viability of the copepod population, have been observed. Predation by hydroids (Heip \& Smol 1976), and a

\footnotetext{
- Contribution No. 910 from the Belle W. Baruch Institute for Marine Biology \& Coastal Research, University of South Carolina

- Addressee for correspondence
}

variety of fishes (Reise 1979, Alheit \& Schiebel 1982, Hicks 1984, Sogard 1984, Gee et al. 1985, Gee 1987) did not appear to significantly alter copepod population size for some epibenthic harpacticoid copepods. Other epibenthic harpacticoid copepods experienced significant abundance declines associated with fish or shrimp predation (Feller \& Kaczynski 1975, Bell \& Coull 1978, Sibert 1979, Bell 1980, Dethier 1980, Warwick et al. 1982, Coull \& Wells 1983, Hicks 1985, Smith \& Coull 1987, Palmer 1988, Ellis \& Coull 1989, Nelson \& Coull 1989). Laboratory experiments imitating predation (Hoppenheit 1975a, b, 1976, Dethier 1980) indicated that constant predation pressure affected abundance and composition of a single species copepod population. The complexity of the question is evident.

This study examines the question of effects of onetime predation on certain aspects of population demo- 
graphics by mimicking controlled predation on a single species population of meiobenthic copepod in a laboratory setting. The null hypothesis tested was that this kind of predation had no effect on population size or stage composition. Confounding factors such as interspecies competition (for food and space), chemical and physical environmental variations over time and space, immigration, emigration and disturbance are minimized by the experimental design. Intraspecific density-related effects are unlikely to influence the outcome, as estimated maximum final density of 10000 copepods per chamber (224 copepods per $10 \mathrm{~cm}^{2}$ ) was similar to mean copepod densities in North Inlet, South Carolina, USA, which was the source of these specimens (Coull \& Dudley 1985).

The experimental copepod Amphiascus tenuiremis (Brady \& Robertson, 1875) cf. Mielke (1974) is an epibenthic, euryhaline harpacticoid. A. tenuiremis conforms to the common harpacticoid copepod life history pattern (Lang 1948) with 6 naupliar and 6 copepodite stage. The sixth copepodite is the sexually mature adult. Clasped pairs may involve Stage 5 females but copulation does not occur and eggs are not extruded until after the fifth copepodid molt. Eggs are carried externally in sacs, from which the nauplii hatch and crawl away.

Body size and behaviour may contribute to stageor gender-specific natural predation on Amphiascus tenuiremis. Mature female copepods are generally larger in size than any other population component, especially when in copula or carrying eggs. Bodiou \& Villiers (1979) reported that the mean size of harpacticoids in goby stomachs was larger than that in the source population and epibenthic harpacticoids were the most commonly observed in the goby. In the laboratory, adult female $A$. tenuiremis spend more time than nauplii, copepodites or males on top of the substrate, in the water column and underneath the water surface. If this behaviour is representative of field populations, then higher relative predation risk to females is likely. Adult males, on the other hand, are smaller and thus at less predation risk. Copepodites exhibit behaviour similar to that of adults but are even smaller than male adults, and thus assume lower predation risk. Nauplii spend most of the time on or in the sediment, rarely venturing into the water column, thereby reducing risk from visually cued predators. This behaviour pattern may result in high exploitation by predators like spot Leiostomus xanthurus which take bites of sediment and filter out organisms for consumption (Billheimer \& Coull 1988). The probable primary predators of this copepod are immature estuarine fishes (Ellis \& Coull 1989, Nelson \& Coull 1989, Feller et al. 1990) some of which may use visual cues for prey location. The experiments reported below provide new information about the population composition of A. tenuiremis, and the potential role of predation in determining its population dynamics.

\section{MATERIALS AND METHODS}

The original source of Amphiascus tenuiremis stock was North Inlet (Georgetown, South Carolina, USA; $33^{\circ} 19^{\prime} \mathrm{N}, 79^{\circ} 10^{\prime} \mathrm{W}$ ) where it inhabits sand and mud communities in Spartina alterniflora Loisel saltmarshes. Seasonal patterns of abundance, gender and life stage ratios are not fully known but this species proved to be easy to maintain in laboratory cultures (following Chandler 1986) and possessed high reproductive potential.

Preliminary experiment. The generation time of Amphiascus tenuiremis was determined by observing 10 gravid females and 10 mating pairs, isolated in individual small petri dishes. These cultures were maintained under the same feeding and environmental conditions as the removal experiments (see below) except that these preliminary experiments were carried out under static conditions, not in the flow-through seawater system. Cultures were examined daily and every individual enumerated by stage and/or gender. Mean generation time (egg to egg) was $20.8 \mathrm{~d}$ (range 20 to $23 \mathrm{~d}$ ) under these static conditions. Thus, we selected $21 \mathrm{~d}, 1$ generation, for our mimicked predation experiments.

Mimicked predation experiments. Predation was mimicked by reducing initial number of 1 of the 3 starting components: adult (gravid and non-gravid) females, adult males and copepodites, and is referred to as 'treatment'. The treatments were called 'female', 'male' and 'copepodite', respectively. Nauplii were not included in initial composition due to the inability to obtain the large numbers required.

We conducted 6 experiments: 3 at $90 \%$ removal of the target population with controls (no removal), and 3 at $50 \%$ removal of the target population with controls (Table 1). Thus each experiment consisted of 2 replicates of the controls and 2 replicates of 3 treatments (Table 1). Ninety percent removal represented $30 \%$ decrease in initial population size and $50 \%$ removal represented $17 \%$ decrease. These removal levels were selected to provide a wide range of one-time 'predation' impact without completely eliminating the target component. Control populations did not have any component removed, and contained 100 copepodites (sex unknown), 100 males and 100 females (approximately $50 / 50$ ovigerous and non-ovigerous). Three experiments, with 2 replicates each, were performed separately and sequentially at the 2 removal levels (Table 1). For example, experiments with $90 \%$ 
Table 1. Amphiascus tenuiremis. Initial composition of experiments, and number of individuals per chamber. Maximum abundance, in control populations, equaled 300 copepods. Each experiment $(90 \%$ removal) and $50 \%$ removal was repeated 3 times

\begin{tabular}{|c|c|c|c|c|}
\hline Treatment & Replicate & Number of & each cor & ponent \\
\hline & & Copepodites & Males & Femal \\
\hline $90 \%$ Remov & val level (E & ts $1,2 \& 3$ ) & & \\
\hline Control & 1 & 100 & 100 & 100 \\
\hline & 2 & 100 & 100 & 100 \\
\hline Copepodite & 1 & 10 & 100 & 100 \\
\hline & 2 & 10 & 100 & 100 \\
\hline Male & 1 & 100 & 10 & 100 \\
\hline & 2 & 100 & 10 & 100 \\
\hline Female & 1 & 100 & 100 & 10 \\
\hline & 2 & 100 & 100 & 10 \\
\hline
\end{tabular}

$50 \%$ Removal level (Expts 4, 5 \& 6)

$\begin{array}{lrrrr}\text { Control } & 1 & 100 & 100 & 100 \\ \text { Copepodite } & 2 & 100 & 100 & 100 \\ & 1 & 50 & 100 & 100 \\ \text { Male } & 2 & 50 & 100 & 100 \\ & 1 & 100 & 50 & 100 \\ \text { Female } & 2 & 100 & 50 & 100 \\ & 1 & 100 & 100 & 50 \\ & 2 & 100 & 100 & 50\end{array}$

removal (Expts 1, 2 \& 3) used initial population sizes of 210 copepods, involving reduction of the 'treatment' component from 100 individuals to 10 individuals. Similarly, 50 \% removal level experiments (Expts 4, 5 \& 6) initially contained 250 copepods with reduction of the 'treatment' component from 100 to 50 individuals (Table 1). All experiments were performed in an environmentally-controlled laboratory, using the flowthrough artificial seawater/culture system designed by Chandler (1986). Salinity averaged 30 ppt, temperature ranged from 22 to $24^{\circ} \mathrm{C}$ and daily photoperiod was $14 \mathrm{~h}$ of light and $10 \mathrm{~h}$ of darkness.

Eight experimental chambers were constructed from cylindrical plastic finger bowls, $10.2 \mathrm{~cm}$ (inner diameter) wide by $4 \mathrm{~cm}$ deep. A $12 \mathrm{~cm}$ length of $0.6 \mathrm{~cm}$ diameter Tygon tubing was snugly inserted into a drainhole $1 \mathrm{~cm}$ from the top of each dish, and a filter made of $44 \mu \mathrm{m}$ Nitex mesh was cemented across the inside of the opening. This prevented organisms from escaping but did not inhibit drainage, and could be easily aspirated clean of algae and waste materials after each feeding. Surface area was $81.7 \mathrm{~cm}^{2}$ and with water level at $3 \mathrm{~cm}$ (determined by drainhole height), habitable volume was $254.8 \mathrm{~cm}^{3}$.

Food in all experiments was frozen, concentrated suspensions of the unicellular alga Isochrysis galbana
(Chrysophyceae, Chrysophyta). Frozen, concentrated algal suspension was brought to room temperature and agitated (to break up cell clumps). An equal volume of well-mixed suspension was pipetted into each experimental chamber every third day in the $21 \mathrm{~d}$ experimental period. Rations were calculated to feed to excess in order to minimize potential influence of food deprivation on reproductive capacity (Ustach 1982, Vilela 1984) and population composition (Hicks \& Coull 1983).

In preparation for each of the 6 experiments, 8 chambers were connected to the seawater system and allowed to fill. An aliquot of autoclaved $44 \mu \mathrm{m}$ sieved sediment (prepared following the procedure in Chandler 1986) was homogenized in seawater and poured into each chamber. After 6 to $8 \mathrm{~h}$ settling time, each chamber contained a smooth layer of sediment $3 \mathrm{~mm}$ thick. Chamber filters were aspirated clean of excess fine sediment to facilitate water drainage, prior to addition of organisms.

Control and treatment populations were assembled from stock cultures. Stock specimens were obtained from muddy sediments from North Inlet, approximately 2 yr (30 generations) prior to the experiments. Stock populations were maintained under the same environmental conditions in a flow-through seawater system, with excess food. Complete assembly of a single experiment required 6 to $8 \mathrm{~h}$ of sorting, necessitating precautions to minimize pre-experiment alteration of population composition. During the sorting period, each treatment was assembled in a separate watch glass, supplied with food and placed in a constant environment chamber, awaiting the start of the experiment. When all 8 populations (per experiment) were assembled, the contents of each watch glass were gently washed into its randomly assigned chamber in the array connected to the seawater system.

After $21 \mathrm{~d}$, the population in each of the 8 chambers was terminated and fixed in a $4 \%$ formaldehyde solution containing Rose Bengal. All copepods were enumerated by life stage and gender in the following categories: nauplius, copepodite, adults. Adults were enumerated as male, gravid female and non-gravid female. Detailed enumeration of the 6 naupliar and 5 immature copepodite (juvenile) stages was not performed.

Data analyses. The original experimental ANOVA model was 2-factor (level of removal and treatment) with a blocking factor (experiment). There was significant interaction between the factors level and experiment, which prohibited statistical comparisons between the 2 levels of removal. Additionally, variability among experiments (of the same level) was often more significant than effects of level of removal, especially at the $90 \%$ level, where Expt 3 had signifi- 
cantly fewer individuals than Expts 1 \& 2. However, the pattern of treatment effects was not significantly different $(F=2.18, \mathrm{p}=0.1183)$ in Expt 3 from that in Expt 1 or 2. Therefore, data from Expt 3 were included in statistical comparisons. At the $50 \%$ level, interexperimental differences were also present but the pattern of treatment effects was similar. Sources of variability could not be specifically identified but pooling gravid and non-gravid females in the female treatments and the unknown ages and gender ratios of the copepodites could have contributed to this variability. The stock population which was the source of all experimental subjects was 30 generations old and was presumed to have a stable age distribution and to be nearly genetically uniform. Due to the high interexperiment variability at each level, analyses of variability were confined to inter-treatment comparisons of population abundance, population composition and gender ratio. Therefore, the original theoretical model changed from blocked, 2-factor, with experiment as the blocking factor, to 3 -factor, with level, experiment and treatment as factors:

$\mathrm{Y}_{i j k}=\mathrm{u}_{i j k}+$ Level $_{i}+$ Experiment $_{j}+$ Treatment $_{k}+\mathrm{E}_{i j k}$

where $\mathrm{u}=$ overall mean; $\mathrm{E}_{i j k}=$ variation between experiments; $i=2(90 \%$ or $50 \%) ; j=3(1,2$ or $3 ; 4,5$ or 6); $k=4$ (control, copepodite, male or female).

All data analyses were performed using SAS Institute (1985) statistical analysis programs. Population size variance and population composition variance were compared within level of removal among treatments using Tukey's multiple comparison of means procedure $(\alpha=0.05)$. In all analyses, values for Replicate 1 and Replicate 2 of each experiment were averaged for use in comparisons.

Population abundance data were $\log _{10}$ transformed to meet ANOVA assumptions of normal distribution. Population composition was compared using abundance of each component and gender ratio (number of females per male).

Estimates of daily rate of predator impact on a single component were calculated from the percentage of copepods initially removed (90 or $50 \%$ out of 300 ) of the experiments. Using raw data, the following quantities were calculated:

Maximum percent impact $=\frac{\text { copepods removed }}{\text { initial abundance }} \times 100$

Minimum percent impact $=\frac{\text { copepods removed }}{\text { final abundance }} \times 100$

Estimated mean percent impact was the average of maximum and minimum percent impact. Estimated daily mean percent impact (dmpi) was obtained by dividing the mean percent impact by 21 , the number of days that each experiment ran.

\section{RESULTS}

\section{Total population abundance}

Final total population size after 1 generation was greater than initial population size in all treatments. In each instance, the magnitude of increase (final total abundance/initial total abundance) was greater than a factor of 10 (Table 2).

Table 2. Amphiascus tenuiremis. Mean increase in abundance (times initial) over 1 generation ( $21 \mathrm{~d}$ ) in the laboratory

\begin{tabular}{|c|c|c|}
\hline \multirow{2}{*}{$\begin{array}{l}\text { Treatment } \\
\text { (Component removed) }\end{array}$} & \multicolumn{2}{|c|}{ Increase in abundance } \\
\hline & $90 \%$ removal & $50 \%$ removal \\
\hline Control & 28.6 & 18.0 \\
\hline Copepodite & 17.4 & 14.8 \\
\hline Male & 24.4 & 16.4 \\
\hline Female & 12.8 & 12.5 \\
\hline
\end{tabular}

A. Population sizes in the $90 \%$ level treatments

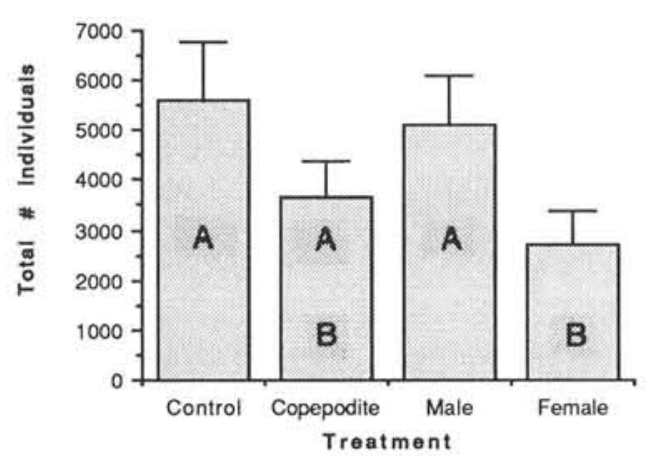

B. Population sizes in the $50 \%$ level treatments

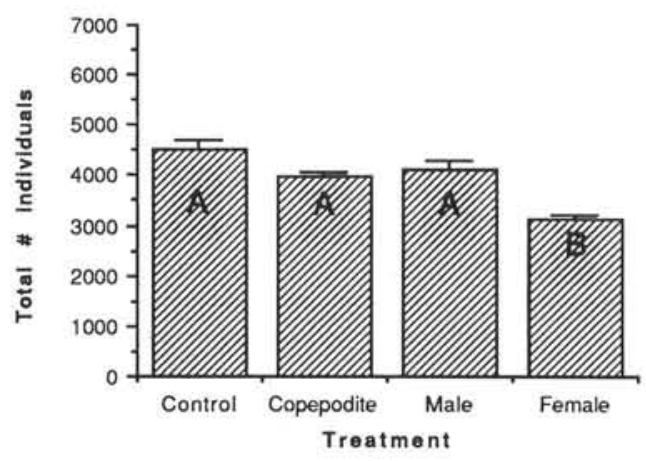

Fig. 1. Mean abundance ( $\mathrm{n}=6$ for each bar) at end of $21 \mathrm{~d}$ for control (no removal), copepodite, male and female removal populations. Error bars $=1 \mathrm{SE}$ of mean. Bars with similar letters are not significantly different from each other (Tukey's multiple comparison procedure; experiment-wise error rate $\leq 0.05$ ) 
Final population abundance was significantly different among treatments at both the 90 and $50 \%$ removal levels. At both removal levels, female removal resulted in total abundance which was significantly lower than that in controls (Fig. 1).

\section{Population composition}

There were treatment effects on abundance of each component (Fig. 2). At the $90 \%$ removal level (Table 3) mean number of nauplii and females was each significantly lower in the female removal treatment and mean number of males was lower in the male removal treatments. Only mean number of copepodites was not significantly different across all treatments (Table 3 ). At the $50 \%$ removal level, mean number of nauplii, copepodites and females each was significantly lower in the female treatment and mean number of males was lower in the male treatment (Table 3, Fig. 2).

\section{A. Composition in $90 \%$ level treatment populations}

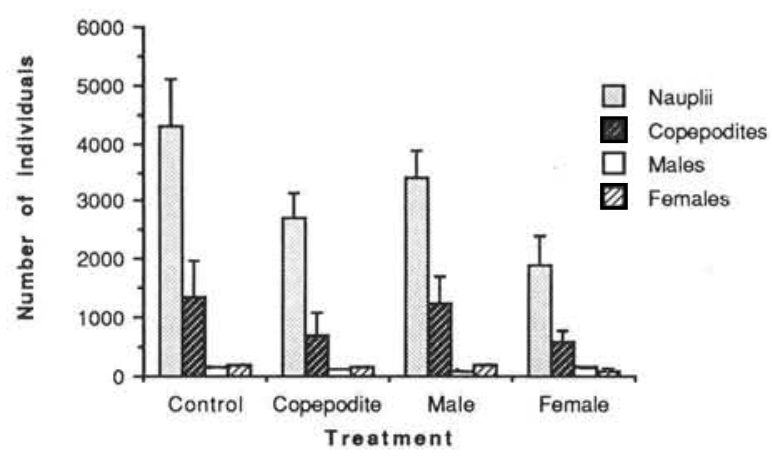

B. Composition in the $50 \%$ treatment populations

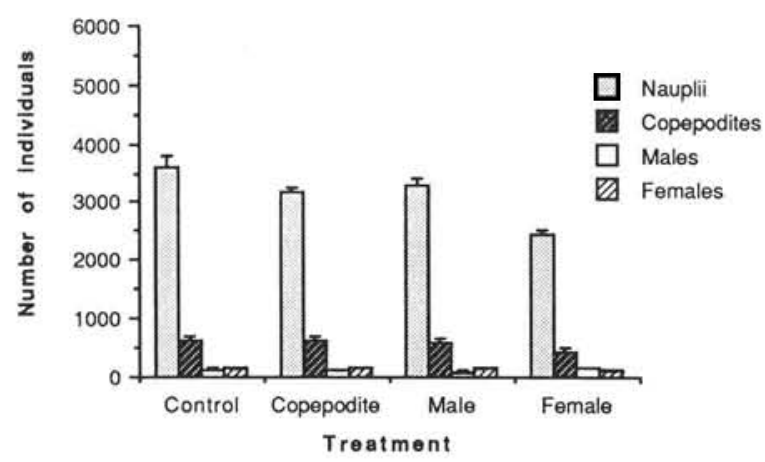

Fig. 2. Mean abundance $+1 \mathrm{SE}$ at end of $21 \mathrm{~d}$ of nauplii, copepodites, males and females in the control (no removal), copepodite, male and female removal treatments. See Table 3 for multiple comparison results on these values
Table 3. Amphiascus tenuiremis, Mean abundance of life history stage (nauplii, copepodites, males, females at end of $21 \mathrm{~d}$ in controls $(\mathrm{C})$, copepodite removal $(\mathrm{J})$, male removal (M) and female removal (F) treatments. Values with a common underline are not significantly different from each other for the particular life history stage (Tukey's multiple comparison procedure; experiment-wise error rate $\leq 0.05$ ): e.g. in the $90 \%$ removal experiments the mean number of nauplii at $21 \mathrm{~d}$ was 4295 in the controls, 3419 in the male removals, 2717 in the copepodite removals and 1894 in female removals and only the number of nauplii in the female treatment was significantly different.

\begin{tabular}{|c|c|c|c|c|}
\hline \multicolumn{2}{|c|}{ Life history stage } & \multicolumn{3}{|c|}{ Mean abundance } \\
\hline \multicolumn{5}{|c|}{$90 \%$ Removal level } \\
\hline Nauplii & $\begin{array}{c}C \\
4295 \\
\end{array}$ & $\begin{array}{c}\text { M } \\
3419\end{array}$ & $\begin{array}{c}\mathrm{J} \\
2717 \\
\end{array}$ & $\begin{array}{c}F \\
1894 \\
\end{array}$ \\
\hline Copepodites & $\begin{array}{c}C \\
1373 \\
\end{array}$ & $\begin{array}{c}\mathrm{M} \\
1245\end{array}$ & $\begin{array}{c}\mathrm{J} \\
684\end{array}$ & $\begin{array}{c}F \\
568\end{array}$ \\
\hline Males & $\begin{array}{c}C \\
147 \\
\end{array}$ & $\begin{array}{c}\mathrm{F} \\
137\end{array}$ & $\begin{array}{c}\mathrm{J} \\
113 \\
\end{array}$ & $\begin{array}{l}\mathrm{M} \\
\underline{75} \\
\end{array}$ \\
\hline Females & $\begin{array}{c}M \\
195 \\
\end{array}$ & $\begin{array}{c}C \\
181\end{array}$ & $\begin{array}{c}\mathrm{J} \\
140 \\
\end{array}$ & $\begin{array}{c}F \\
90 \\
\end{array}$ \\
\hline \multicolumn{5}{|c|}{$50 \%$ Removal level } \\
\hline Nauplii & $\begin{array}{c}\mathrm{C} \\
3608 \\
\end{array}$ & $\begin{array}{c}\mathrm{M} \\
3295 \\
\end{array}$ & $\begin{array}{c}\mathrm{J} \\
3155 \\
\end{array}$ & $\begin{array}{c}F \\
2436 \\
\end{array}$ \\
\hline Copepodites & $\begin{array}{c}C \\
626 \\
\end{array}$ & $\begin{array}{c}\mathrm{J} \\
607 \\
\end{array}$ & $\begin{array}{c}\mathrm{M} \\
562 \\
\end{array}$ & $\begin{array}{r}F \\
431 \\
\end{array}$ \\
\hline Males & $\begin{array}{c}F \\
144 \\
\end{array}$ & $\begin{array}{c}\mathrm{C} \\
125 \\
\end{array}$ & $\begin{array}{c}\mathrm{J} \\
121 \\
\end{array}$ & $\begin{array}{l}M \\
89 \\
\end{array}$ \\
\hline Females & $\begin{array}{c}M \\
155 \\
\end{array}$ & $\begin{array}{c}\mathrm{C} \\
149\end{array}$ & $\begin{array}{c}\mathrm{J} \\
137 \\
\end{array}$ & $\begin{array}{c}\mathrm{F} \\
103 \\
\end{array}$ \\
\hline
\end{tabular}

\section{Gender ratio}

There were treatment effects on gender ratio at each removal level (Fig. 3). At the $90 \%$ removal level, gender ratio was significantly higher in male removal treatment populations than in copepodite removal, female removal treatment or control populations. Gender ratio was also significantly different between control and female treatment populations. At the $50 \%$ removal level, gender ratio was significantly higher in male treatments and lower in female treatment populations, compared to control and copepodite removal treatment populations, which were not significantly different from each other (Fig. 3).

\section{Daily mean percent impact}

At the $90 \%$ removal level, treatment effects were not definitive (Table 4), but at the $50 \%$ removal level female removal treatment had a significantly higher 
A. Mean gender ratio in the $90 \%$ level treatments

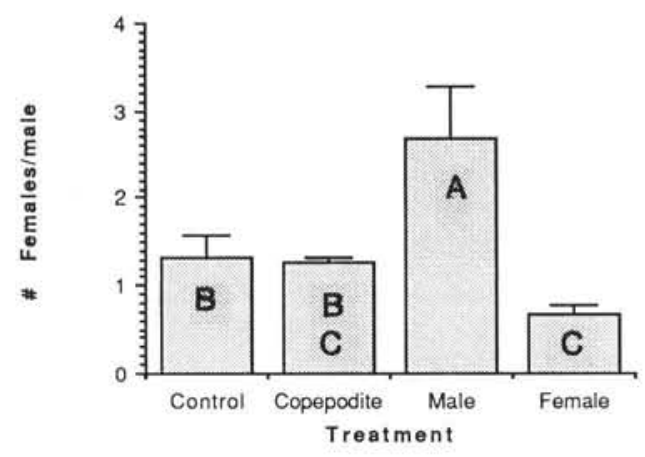

B. Mean gender ratio in the $50 \%$ level treatments

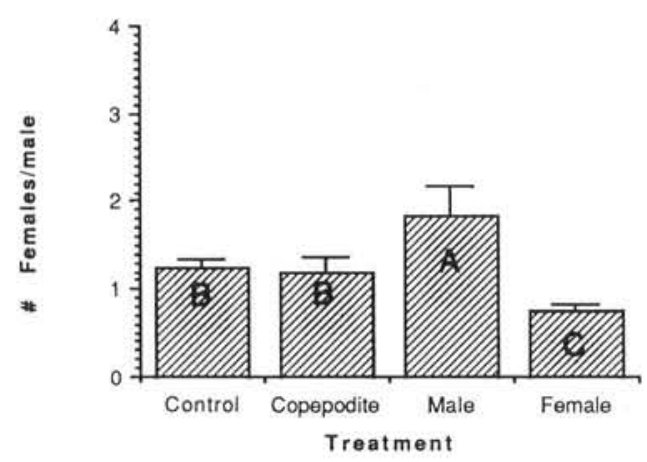

Fig. 3. Mean gender ratios $(\mathrm{n}=6$ for each bar) at end of $21 \mathrm{~d}$ for control, copepodite, male and female removal treatments. Error bars are $\pm 1 \mathrm{SE}$

impact on the population (Table 4) than the removal of any other single population component.

\section{DISCUSSION}

\section{Effects of removal on total population abundance}

Each population increased in abundance by a factor (mean final abundance/initial abundance) greater than 10-fold (Table 2), independent of treatment, indicating the high potential fecundity of Amphisascus tenuiremis in the optimal environmental conditions provided. Only the initial removal of females from the population had an effect on subsequent population size (Fig. 1), primarily due to either significant decreases in number of nauplii produced or high naupliar mortality, compared to number of nauplii in the other treatments and controls (Fig. 3). Reduction of number of adult males did not have similar effects. Females of most harpacticoids (and presumably $A$. tenuiremis) have the ability to store sperm (Hicks \& Coull 1983) and thus reduce dependence of uninterrupted egg production on continuous presence or high density of males.
Table 4. Results of ANOVA comparison of daily mean percent impact (dmpi) at 90 and $50 \%$ removal levels. See Table 3 for definition of 'component removed' letters. Tukey results with the same letter are not significantly different at $\alpha=0.05$

\begin{tabular}{|ccc|}
\hline Component removed & DMPI & Tukey result \\
\hline $\mathbf{9 0} \%$ Removal level & & \\
C & 0.763 & B \\
M & 0.770 & B \\
J & 0.789 & A B \\
F & 0.876 & A \\
& & \\
$\mathbf{5 0}$ Removal level & & \multicolumn{2}{c}{} \\
C & 0.423 & B \\
M & 0.426 & B \\
J & 0.427 & B \\
F & 0.435 & A \\
\hline
\end{tabular}

Copepodite removals had little effect on total population abundance (Fig. 2, Table 3 ) because the percentage of copepodites removed (30 and $17 \%$ for 90 and $50 \%$ removal, respectively) was lower than copepodite mortality rates. Recruitment (survival of nauplii) was less than $17 \%$ so that the impact of mimicked predation could not be distinguished from low recruitment. Feller (1980) reported $25 \%$ copepodite mortality for Huntemannia jadensis and estimates of 33 to $36 \%$ copepodite mortality were obtained from a life table for Tisbe holothuriae (Bergmans 1981).

Naupliar reductions were not performed in our experiments, but initial removal of nauplii should not have had significant effects on final total abundance, given the known high naupliar mortality in harpacticoids. D'Apolito \& Stancyk (1979) calculated $85 \%$ naupliar mortality for Euterpina acutifrons in the laboratory. Feller (1980) observed 32 to $100 \%$ naupliar mortality for Huntemannia jadensis and Bergmans (1981) reported $44 \%$ naupliar mortality for Tisbe holothuriae. Fleeger (1979) and Palmer (1980) concluded that high death rates for Microarthridion littorale were due to high naupliar mortality because nauplii were the numerically dominant life stage. Based on these findings, the highest removal level employed herein $(30 \%)$ would not have significantly affected final naupliar abundance. A posteriori confirmation is evident in our estimated naupliar survival (mean final percentage of copepodites), which ranged from 14 to $16 \%$. Population size was most reduced by initial removal of females, due to significant decreases in number of nauplii. Predation or any disturbance which selectively impacts females, the population component which controls the reproductive capacity of Amphiascus tenuiremis, has the highest potential to decrease population abundance. 


\section{Effects of removal on population composition}

Low juvenile survival (nauplii and copepodites, combined) was indicated in the low final adult male and female abundances, which were lower than copepodite and nauplii abundance in all treatments (Fig. 2) despite the high reproductive potential of Amphiascus tenuiremis (Table 2). Male replacement was low in the male removal treatments and female replacement was depressed in the female removals (see gender ratios, Fig. 3). In each of these treatments, the 100 copepodites and many more maturing nauplii should have been able to replace the 90 adult males or females removed. Thus, survival to adulthood must have been less than $17 \%$ (loss of 90 individuals out of 300). A. tenuiremis completes its life cycle in $21+1 \mathrm{~d}$ under these conditions so all of the initially-present copepodites and some early-hatched nauplii could have matured within the experimental period. The low final abundances of adults, coupled with high reproductive potential (Table 2) indicated low survival of nauplii and copepodites. High adult mortality could potentially be responsible for the low adult numbers, but our observations on stock-cultured $A$. tenuiremis indicate they live 60 to $90 \mathrm{~d}$. Thus there is no a priori reason to assume increased adult mortality in our treatments. In our experiments, mean final number of adults ranged from 6.0 to $15.8 \%$ of the final total population size.

Under the experimental conditions, Amphiascus tenuiremis did not display any compensating mechanism to combat the effects of 90 or $50 \%$ loss of its reproductive potential. If it had, there would have been no treatment effects on population size, composition or gender ratio. Tisbe holothuriae use compensation mechanisms in response to imitation predation: $90 \%$ weekly population reduction reduced egg development rate and naupliar mortality and increased survival of males (Hoppenheit 1975b, 1976). A. tenuiremis may not have these mechanisms. Our experiments were probably too short a duration (1-generation) treatments for compensating mechanisms to be invoked.

While our 2 levels of predation each elicited responses from the copepod populations, the levels of impact imposed were not different enough to delineate upper and lower boundaries of potential effects on population size and composition. The less severe of the 2 treatments caused responses similar to the severe treatment. Impacts of greater than $90 \%$ removal of copepodites or males would be required to show significant abundance/composition effects. Similarly, impacts of less than $50 \%$ removal of females would be required to determine level of no effects,

\section{Types of potential responses to predation pressure}

Natural copepod assemblages have been found to be highly variable in species composition and temporal abundance (e.g. Hicks 1979, Hicks \& Coull 1983, Gee \& Warwick 1984, Coull \& Dudley 1985, Johnson \& Scheibling 1986, Palmer 1988). Using highly controlled populations, limited diversity taxocenes (e.g. laboratory-raised monocultures or assemblages) or naturally occurring low diversity assemblages should help to separate effects of environmental and genetic variation from effects of the imposed experimental treatments. To date, few studies of the population dynamics of harpacticoid monocultures have been conducted. Dethier (1980) conducted field and laboratory studies of Tigriopus californicus, which inhabits high intertidal pools with few other occupants. She reported significant decreases in abundance of the copepod due to predation by fish or sea anemones during periods of 1 to $4 \mathrm{~d}$. Such effects, which are basically the primary reactions to a disturbance, may indicate that the organisms did not or could not compensate by altering reproductive rates. These types of effects which do not appear to involve any response by the affected organisms are defined herein as 'first order effects', or 'passive responses' and are associated with short term or rare, intermittent disturbances. Potential for long-term changes in population composition was addressed by Hoppenheit $(1975 b, 1976)$ in a series of predationimitation experiments with Tisbe holothuriae. His results, over an observation period of $24 \mathrm{wk}$, indicated that significant alterations of the population resulted from long-term, constant predation pressure. He observed changes in gender ratios, egg viability rates and naupliar and male mortality - effects which probably indicate that compensating mechanisms had been invoked. We define the efforts of a disturbed population to restore demographic parameters to predisturbance levels or values, especially under conditions of constant predation pressure, as 'second order effects' or 'active responses'. These types of mechanisms would eventually become a part of the evolutionarily stable strategy of the population if predation was constant and persistent for a long enough time.

The 1-generation time course of our experiments does not allow for long-term compensating mechanisms sensu Hoppenheit $(1975 b, 1976)$ and our results are obviously first order effects, despite the fact that the experiments covered $100 \%$ of the generation time (defined as long term; (Wilson \& Bossert 1971). The observed effects of stage or gender specific predation were only passive responses, involving reduction of total abundance and nauplii. Amphiascus tenuiremis most likely does not possess the physiological flexibility to alter fecundity within 
1 generation and more than 1 generation would be required to stabilize gender ratio after catastrophic demographic pertubation.

\section{Predation impact}

It is generally assumed that predation is a continuous or regularly occurring event and not a one time event as we mimicked. Yet we are unaware of quantitative data on the predation frequency on a harpacticoid population in the field. The presence of copepods in predator guts over time does not unequivocally mean that the same prey population was eaten each time. In the southeastern United States schools of harpacticoid feeding juvenile spot Leiostomus xanthurus swim onto a mudflat, feed on some portion of the flat (often a very small portion of 1 or $2 \mathrm{~m}$ ) and swim off. Observing 1 mudflat over $4 \mathrm{~d}$ we did not observe another spot school on that flat, indicating that at least over $4 \mathrm{~d}$ there was not a continuous predation impact on the resident harpacticoids, yet juvenile spot almost always have harpacticoids in their guts (Feller et al. 1990). Whether the fish returned to the same mudflat within $21 \mathrm{~d}$ (the time of our experiment) is unknown. Thus while we mimicked a once in time predation event, we did so because of our observations on feeding spot in South Carolina. Our experiments then should be viewed as simulating natural conditions but perhaps at a low predation rate.

Impact of predator exploitation on copepod populations has been calculated for a variety of predators ranging from juvenile flatfish (Hicks 1985) to shrimp
(Gee 1987). A summary of estimated predator effects on various field populations of harpacticoid copepods is presented in Table 5. In each example, a single species was the dominant prey item and represented a large proportion of the copepod assemblage. Estimates of daily consumption rate of the dominant predators ranged from 0.01 to $3.45 \%$. In each case, the author concluded that predation at the above-stated rates would not significantly alter the respective copepod population.

In our experiments, female removal at the $90 \%$ removal level resulted in the highest daily mean percent impact removal level, $0.876 \% \mathrm{~d}^{-1}$, and female removal at the $50 \%$ removal level, $0.435 \% \mathrm{~d}^{-1}$ (Table 4). These values are comparable to published estimates of predation impact where there was little or no observable effects on the copepod populations. Therefore, the changes which were observed in abundance and composition of the populations of Amphiascus tenuiremis should not be long lasting. These first order effects would have probably been eliminated within the next few generations, given the high reproductive potential of this copepod. Since compensating mechanisms were not involved with $A$. tenuiremis, we conclude that the imitated predation pressure which we invoked was not severe or long enough to require such strategies. Daily predation pressures of 12.8 and $7.1 \%$ on Tisbe holothuriae populations (Hoppenheit 1976) resulted in compensation mechanisms: rates are 4 to 200 times higher than reported field values. Our field-comparable results suggest that $A$. tenuiremis did not, or would not, require alteration of physiological parameters to cope with predation.

Table 5. Selected literature on predator impacts on benthic harpacticoid copepods

\begin{tabular}{|c|c|c|c|c|}
\hline Predator & Prey & $\begin{array}{l}\text { Removal by } \\
\text { predator }\left(\% \mathrm{~d}^{-1}\right)\end{array}$ & Conclusion & Source \\
\hline $\begin{array}{l}\text { Tomtate } \\
\text { Haemulon aurolineatum }\end{array}$ & $\begin{array}{l}\text { Longipedia } \\
\text { helgolandica }\end{array}$ & 0.02 & $\begin{array}{l}\text { Predicted no impact } \\
\text { at } 0.1 \% \mathrm{~d}^{-1}\end{array}$ & Alheit \& Scheibel (1982) \\
\hline $\begin{array}{l}\text { Spotted dragonet } \\
\text { Callionymus pauciradiatus }\end{array}$ & Harpacticoids & $0.05-3.45$ & $\begin{array}{l}\text { No impact at } 3 \times \\
\text { observed fish density }\end{array}$ & Sogard (1984) \\
\hline Juvenile flatfish & $\begin{array}{l}\text { Parastenhelia } \\
\text { megarostrum }\end{array}$ & 0.38 & No impact & Hicks (1985) \\
\hline Plaice Pleuronectes platessa & $\begin{array}{l}\text { Asellopsis } \\
\text { intermedia }\end{array}$ & $0.012-0.097$ & $\begin{array}{l}\text { None, unless predator } \\
\text { abundance } 1000 \times \text { higher }\end{array}$ & Gee (1987) \\
\hline Shrimp Crangon crangon & $"$ & $0.015-0.097$ & $"$ & $"$ \\
\hline $\begin{array}{l}\text { Gobies Pomatoschistus microps } \\
\text { and } P \text {. minutus }\end{array}$ & $"$ & 0.015 & " & $"$ \\
\hline Gobies, plaice, shrimp & $"$ & $0.01-0.10$ & $"$ & $"$ \\
\hline
\end{tabular}


Gobies and blennies are reported to preferentially prey on large or female benthic copepods (Bodiou et Villiers 1979, Coull \& Wells 1983, respectively) but a flatfish selectively preyed on nauplii (Hicks 1984). If size or gender-specific predation on harpacticoids is commonplace in the field, and our controlled mimicked predation is indicative, then only the removal of females would have an effect on population size. If the prey copepod has the ability to reproduce rapidly (sensu Amphiascus tenuiremis), then predation effects on demographic parameters should not be long lasting, unless the predation pressure is continuous. Most harpacticoid copepods apparently have the ability to out-reproduce any removal due to predation.

Acknowledgements. We thank Drs R. J. Feller and S. E. Stancyk, and 3 anonymous reviewers for critical reading of earlier drafts of this manuscript and Dr D. Edwards for statistical consultation. We especially thank Dr G. T. Chandler for his advice and assistance in culturing. This research was part of the Master of Science degree requirements in Marine Science at the University of South Carolina by R. E. Woods and supported by the Oceanography Program of the National Science Foundation, Grant No. OCE89-16255 (B. C. Coull, Principal Investigator).

\section{LITERATURE CITED}

Alheit, J., Schiebel, W. (1982). Benthic harpacticoids as food for fish. Mar. Biol. 76: 141-147

Bell, S. S. (1980). Meiofauna-macrofauna interactions in a high salt marsh habitat. Ecol. Monogr. 50: 487-505

Bell, S. S., Coull, B. C. (1978). Field evidence that shrimp predation regulates meiofauna. Oecologia 35: 141-148

Bergmans, M. (1981). A demographic study of the life cycle of Tisbe furcata (Baird 1837) (Copepoda, Harpacticoida). J. mar. biol. Ass. U. K. 61: 691-705

Billheimer, L. E., Coull, B. C. (1988). Bioturbation and recolonization of meiobenthos in juvenile spot (Pisces) feeding pits. Estuar. coast. Shelf Sci. 27: 335-340

Bodiou, J. Y., Villiers, L. (1979). La predation de la meiofaune par les forms juveniles de Deltentosteus quadrimaculatus (Teleostei, Gobiidae). Vie Milieu 28-29: 143-156

Chandler, G. T. (1986). High density culture of meiobenthic harpacticoid copepods within a muddy substrate. Can. J. Fish. Aquat. Sci. 43: 53-59

Coull, B. C., Dudley, B. W. (1985). Dynamics of meiobenthic copepod populations: a long term study (1973-1983). Mar. Ecol. Prog. Ser. 24: 219-229

Coull, B. C., Palmer, M. A. (1984). Field experimentation in meiofaunal ecology. Hydrobiologia 118: 1-19

Coull, B. C., Wells, J. B. J. (1983). Refuges from fish predation: experiments with phytal meiofauna from the New Zealand rocky intertidal. Ecology 64: 1599-1609

D'Apolito, L. M., Stancyk, S. E. (1979). Population dynamics of Euterpina acutifrons (Copepoda: Harpacticoida) from North Inlet, South Carolina, with reference to dimorphic males. Mar. Biol. 54: 251-260

Dethier, M. N. (1980). Tidepools as refuges: predation and limits of the harpacticoid copepod Tigriopus californicus (Baker). J. exp. mar. Biol. Ecol. 42: 99-111

Ellis, M. J., Coull, B. C. (1989). Fish predation on meiobenthos: field experiments with juvenile spot Leiostomus xanthurus Lacepede. J. exp. mar. Biol. Ecol. 130: 19-32

Feller, R. J. (1980). Development of the sand dwelling meiobenthic harpacticoid copepod Huntemannia jadensis Poppe in the laboratory. J. exp. mar. Biol. Ecol. 46: 1-15

Feller, R. J., Coull, B. C., Hentschel, B. T. (1990). Meiobenthic copepods: tracers of where juvenile Leiostomus xanthurus (Pisces) feed? Can. J. Fish. Aquat. Sci. 47: 1913-1919

Feller, R. J., Kaczynski, V. W. (1975). Size selective predation by juvenile chum salmon on epibenthic prey in Puget Sound. J. Fish. Res. Bd Can. 32: 1419-1429

Fleeger, J. W. (1979). Population dynamics of three estuarine meiobenthic harpacticoids (Copepoda) in South Carolina. Mar. Biol. 52: 147-156

Gee, J. M. (1987). Impact of epibenthic predation on estuarine intertidal harpacticoid populations. Mar Biol. 96: 497-510

Gee, J. M., Warwick, R. M. (1984). Preliminary observations on the metabolic and reproductive strategies of harpacticoid copepods from an intertidal sandflat. Hydrobiologia 118: $29-37$

Gee, J. M., Warwick, R. M., Davey, J. T., George, C. L. (1985). Field experiments on the role of epibenthic predators in determining prey densities in an estuarine mudflat. Estuar. coast. Shelf Sci. 21: 429-448

Heip, C., Smol, N. (1976). On the importance of Protohydra leuckarti as a predator of meiobenthic populations. In: Persoone, G., Jaspers, E. (eds.) Proc. 10th Eur. mar. biol. Symp. Universa Press, Wetteren, 2: 285-296

Hicks, G. R. F. (1979). Pattern and strategy in the reproductive cycles of benthic harpacticoid copepods. In: Naylor, E., Marshall, R. G. (eds.) Cyclic phenomena in marine plants and animals. Pergamon Press, Oxford, p. 139-147

Hicks, G. R. F. (1984). Spatio-temporal dynamics of a meiobenthic copepod and the impact of predation-disturbance. J. exp. mar. Biol. Ecol. 81: 47-72

Hicks, G. R. F. (1985). Biomass and production estimates for an estuarine meiobenthic copepod, with an instantaneous assessment of exploitation by flatfish predators. N.Z. J. Ecol. 8: 125-127

Hicks, G. R. F., Coull, B. C. (1983). The ecology of marine meiobenthic copepods. Oceanogr. mar. Biol. A. Rev. 21: $67-125$

Hoppenheit, M. (1975a). Zur Dynamik exploitierter Populationen von Tisbe holothuriae (Copepoda, Harpacticoida). I. Methoden, Verlauf der Populationsentwicklung und Einfluß der Wasserneuerung. Helgoländer wiss. Meeresunters. 27: $235-253$

Hoppenheit, M. (1975b). Zur Dynamik exploitierter Populationen von Tisbe holothuriae (Copepoda, Harpacticoida). II. Populationdichte, Wachstum und Ausbeute. Helgoländer wiss. Meeresunters. 27: 377-395

Hoppenheit, M. (1976). Zur Dynamik exploitierter Populationen von Tisbe holothuriae (Copepoda, Harpacticoida). III. Reproduktion, Geschlechtsverhältnis, Entwicklungsdauer und Überlebenszeit. Helgoländer wiss. Meeresunters. 28: 109-137

Johnson, S. C., Schiebling, R. E. (1987). Structure and dynamics of epifaunal assemblages on intertidal macroalgae Ascophyllum nodosum and Fucus vesiculosus in Nova Scotia, Canada. Mar. Ecol. Prog. Ser. 37: 209-227

Lang, K. (1948). Monographie der Harpacticiden, I and II. Hakan Ohlsson, Lund

Nelson, A., Coull, B. C. (1989). Selection of meiobenthic prey by juvenile spot (Pisces): an experimental study. Mar. Ecol. Prog. Ser. 53: 51-57

Palmer, M. A. (1980). Variation in life history patterns between intertidal and subtidal populations of the meiobenthic copepod Microarthridion littorale Poppe. Mar. 
Biol. 60: 159-165

Palmer, M. A. (1988). Epibenthic predators and marine meiofauna: separating predation, disturbance and hydrodynamic effects. Ecology 69: 1251-1259

Reise, K. (1979). Moderate predation on meiofauna by macrobenthos of the Wadden Sea. Helgoländer wiss. Meeresunters. 36: 453-465

SAS Institute (1985). SAS user's guide: statistics version 5. SAS Institute, Cary, North Carolina

Sibert, J. (1979). Detritus and juvenile salmon production in the Nanaimo estuary: II. Meiofauna available as food to juvenile chum salmon (Oncorhynchus keta). J. Fish. Res. Bd Can. 36: 497-503

Smith, L. D., Coull, B. C. (1987). Juvenile spot (Pisces) and grass shrimp predation on meiobenthos in muddy and sandy substrates. J. exp. mar. biol. Ecol. 105: 123-136

This article was submitted to the editor
Sogard, S. M. (1984). Utilization of meiofauna as a food source by a grassbed fish, the spotted dragonet, Callionymus pauciradiatus. Mar. Ecol. Prog. Ser. 17: 183-191

Ustach, J. F. (1982). Algae, bacteria and detritus as food for the harpacticoid copepod, Heteropsyllus pseudonunni Coull and Palmer. J. exp. mar. Biol. Ecol. 64: 203-214

Vilela, M. H. (1984). Production experiments of the marine harpacticoid Tigriopus brevicornis Muller, reared on various feeding regimes. Bol. Inst. Nac. Invest. Pescas, Lisboa 11: 83-115

Warwick, R. M., Davey, J. T., Gee, J. M., George, C. L. (1982). Faunistic control of Enteromorpha blooms: a field experiment. J. exp. mar. Biol. Ecol. 56: 23-31

Wilson, E. O., Bossert, W. H. (1971). A primer of population biology. Sinauer Associates Inc., Publishers, Sunderland, Massachusetts

Manuscript first received: July 12, 1991

Revised version accepted: December 9, 1991 